\title{
Efektivitas Terapi Rendam Kaki Air Hangat terhadap Perubahan Penurunan Tekanan Darah Ibu Hamil Preeklampsia
}

\author{
Maslahatul Inayah, Tri Anonim \\ Email: inakiya74@gmail.com \\ D III Keperawatan, Prodi Pekalongan, Poltekkes Kemenkes Semarang, Indonesia \\ Jalan Perintis Kemerdekaan Pekalongan \\ Telp/Fax. (0285) 429373 / 421642
}

\begin{abstract}
Abstrak
Kesehatan baik pada masa kehamilan maupun masa nifas. Ibu hamil dengan preeklampsia dapat menyebabkan terjadinya komplikasi yang mengakibatkan meningkatnya angka kematian ibu maupun kematian perinatal. Ada beberapa upaya untuk mengendalikan tekanan darah tinggi. Cara tersebut dapat menggunakan farmakologis maupun non farmakologis. Tujuan penelitian ini adalah untuk mengetahui efektivitas terapi rendam kaki air hangat terhadap perubahan penurunan tekanan darah ibu ha Angka Kematian Ibu (AKI) dapat menjadi alat ukur untuk mengetahui kualitas pelayanan mil preeklampsia.Jenis penelitian ini adalah penelitian kuantitatif dengan desain penelitian quasi-eksperiment, dengan pendekatan rancangan pre and post test pada kelompok intervensi dan kelompok kontrol. Sampel untuk tiap kelompok 10 orang, sehingga jumlah total sampel adalah 20 responden.Analisis bivariat dilakukan dengan menggunakan uji wilxocon karena distribusi data tidak normal dan Mann-Whitney Test untuk mengetahui perbedaan sebelum dan sesudah diberikan intervensi. Hasil analisis bivariat menunjukkan bahwa ada pengaruh pemberian terapi rendam kaki air hangat terhadap perubahan penurunan tekanan darah sistolik dan diastolik ibu hamil preeklampsia dengan nilai $\mathrm{p}=0,004$ dan $\mathrm{p}=0,011$ serta ada perbedaan perubahan penurunan tekanan darah sistolik dan diastolik antara kelompok intervensi dengan kelompok kontrol dengan $\mathrm{p}=0,001$ dan $\mathrm{p}=0,007$.
\end{abstract}

Kata Kunci: rendam kaki air hangat; tekanan darah; ibu hamil preeklampsia.

\begin{abstract}
Maternal Mortality Rate (MMR) can be a measuring tool to determine the quality of health services both during pregnancy and postpartum. Pregnant women with preeclampsia can cause complications that lead to increased maternal mortality and perinatal mortality. There are several attempts to control high blood pressure. This method can use pharmacological or non pharmacological. The purpose of this study was to determine the effectiveness of warm water foot soak therapy on changes in blood pressure reduction of preeclamptic pregnant women. This type of research is a quantitative study with aresearch quasi-experimentaldesign, with adesign approach pre and post test in the intervention group and the conMtrol group. The sample for each group is 10 people, so that the total number of samples is 20 respondents.Bivariate analysis was performed using the Wilxocon test because the data distribution was not normal and the Mann-Whitney Test to determine the difference before and after the intervention was given. The results of the bivariate analysis showed that there was an effect of giving warm water foot soaking therapy to changes in the decrease in systolic and diastolic blood pressure of preeclamptic pregnant women with a value of $p=0.004$ and $p=0.011$ and there were differences in changes in the decrease in systolic and diastolic blood pressure between the intervention group and the control group. $p=0.001$ and $p=$ 0.007 .
\end{abstract}

Keywords: warm water soak feet; blood pressure; preeclamptic pregnant women. 
Jurnal Kebidanan Harapan Ibu Pekalongan

\section{Pendahuluan}

A. Latar Belakang

Angka Kematian Ibu (AKI) dapat menjadi alat ukur untuk mengetahui kualitas pelayanan kesehatan baik pada masa kehamilan maupun masa nifas. Meningkatnya derajat kesehatan ibu merupakan salah satu tujuan Sustainable Development Goals (SDGs) yang ingin dicapai pada tahun 2030. Target SDGs 2030 adalah menurunkan Angka Kematian Ibu (AKI) hingga kurang dari 70 per 100.000 KH.Salah satu penyebab kematian maternal terbesar adalah preeklampsia. Dari 26 Puskesmas di wilayah Dinas Kesehatan Kabupaten Pekalongan, angka kejadian preeklampsia tertinggi di 8 (delapan) wilayah puskesmas yang mempunyai karakter wilayah serupa yaitu Kedungwuni I, Kedungwuni II, Karangdadap, Buaran, Wiradesa, Tirto, Buaran dan Wonopringgo. Ibu hamil dengan preeklampsia dapat menyebabkan terjadinya komplikasi yang mengakibatkan meningkatnya angka kematian ibu maupun kematian perinatal. Komplikasi maternal akibat preeklamsia antara lain eklamsia, kelainan pembekuan darah, sindrom HELPP. Sedangkan komplikasi pada janin adalah asfiksia neonatarum, prematur dan IUFG.

$$
\text { Preeklampsia adalah }
$$

timbulnya hipertensi di sertai proteinuria dan edema akibat kehamilan setelah umur kehamilan 20 minggu. Salah satu gejala khas preeklampsia adalah hipertensi yaitu suatu kondisi peningkatan tekanan darah diatas normal yang ditunjukkan dengan peningkatan nilai sistolik dan diastolik. Peningkatan tekanan darah menyebabkan pembuluh darah vasokontriksi dan dapat mengakibatkan suplai oksigen dan nutrisi ke jaringan dan organ tubuh akan berkurang sehingga dapat menyebabkan tidak berfungsinya organ bahkan kematian.

Ada beberapa upaya untuk mengendalikan tekanan darah tinggi. Cara tersebut dapat menggunakan farmakologis maupun non farmakologis. Salah satu tindakan non farmakologis yang dapat di lakukan untuk menurunkan tekanan darah tinggi pada penderita preeklampsia dengan memberikan teknik hidroterapi yang salah satunya dengan tindakan rendam kaki menggunakan air hangat.rendam kaki menggunakan air hangat akan merangsang syaraf yang ada di kaki untuk bekerja dan berfungsi mendilatasi pembuluh darah serta melancarkan peredaran darah.

Penelitian yang dilakukan oleh Cristinina Febrinina S (2016) menyebutkan bahwa rendam kaki air hangat efektif terhadap penurunan tekanan darah ibu hamil preekalmpsia.

B. Tinjauan Pustaka

Terapi rendam kaki air hangat merupakan bentuk terapi yang menggunakan media air atau di sebut dengan hidroterapi adalah metode pengobatan menggunakan air untuk mengobati penyakit atau meringankan kondisi yang menyakitkan. Keuntungan dari hidroterapi ini antara lain untuk mengurangi nyeri dan kekakuan 
Jurnal Kebidanan Harapan Ibu Pekalongan

otot, meningkatkan relaksasi otot dan mempercepat penyembuhan.

Pre-eklamsia merupakan suatu kondisi spesifik kehamilan dimana hipertensi terjadi setelah minggu ke-20 pada wanita yang sebelumnya memiliki tekanan darah normal.

Sampai saat ini penyebab pre-eklamsia belum diketahui dengan pasti akan tetapi ada beberapa faktor risiko atau faktor predisposisi terjadinya preeklamsia antara lain :

a) Primigravida atau multipara dengan usia lebih tua (Usia < 18 atau $>35$ ).

b) Obesitas

c) Adanya proses penyakit kronis:

d) Diabetes Mellitus

e) Hipertensi

f) Penyakit ginjal

g) Penyakit pembuluh darah

h) Penyakit pembuluh darah kolagen (Lupus Eritematosus Sistemik).

i) Kehamilan molahidatidosa

Klasifikasi pre-eklamsia:

a). Pre-eklamsia Ringan

Timbulnya hipertensi yaitu 140/110 mmHg yang disertai proteinuria dan atau edema umur kehamilan 20 minggu.

b). Pre-eklamsia Berat

Suatu komplikasi kehamilan yang ditandai dengan timbulnya hipertensi $\geq 160 / 110$ disertai proteinuria dan atau edema pada kehamilan $\geq 20$ minggu, keluhan subyektif seperti nyeri epigastrium, gangguan penglihatan, nyeri kepala, edema paru dan sianosis, gangguan kesadaran, pemeriksaan kadar enzim hati meningkat disertai ikterus, perdarahan pada retina, trombosit kurang dari $100.000 / \mathrm{mm}$.

\section{Tujuan Penelitian \\ Untuk mengetahui pengaruh terapi rendam kaki air hangat terhadap perubahan penurunan tekanan darah ibu hamil preeklampsia.}

\section{Metode Penelitian}

Kerangka Konsep Penelitian

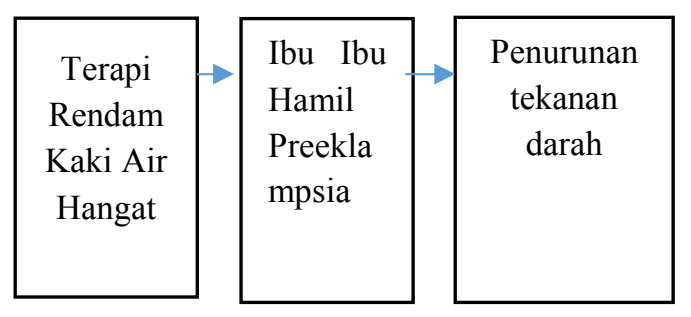

Jenis penelitian ini adalah penelitian kuantitatif dengan desain penelitian quasi-eksperiment,dengan pendekatan rancangan pre and post test pada kelompok intervensi dan kelompok kontrol. Penelitian ini mengukur pengaruh pemberian intervensi terapi rendam kaki air hangat terhadap perubahan penurunan tekanan darah ibu hamil preeklampsia.

Sampel dalam penelitian ini adalah ibu hamil dengan preeklampsia di Wilayah Dinas Kesehatan Kab / Kota Pekalongan. Teknik pengambilan sampel dalam penelitian ini adalah consecutive sampling, dimana semua subjek penelitian yang ada dan memenuhi kriteria di masukkan ke dalam penelitian sampai batas waktu tertentu. Pada penelitian ini total sampel yang digunakan sejumlah 20 responden, dengan jumlah sampel 10 untuk kelompok perlakuan dan 10 sampel untuk kelompok .

Sampel yang menjadi responden dalam penelitian ini adalah yang memenuhi beberapa kriteria inklusi dan ekslusi sebagai berikut: 
Jurnal Kebidanan Harapan Ibu Pekalongan

a). Kriteria Inklusi

1) Umur kehamilan $\geq 20$ minggu

2) Bersikap kooperatif

b). Kriteria Ekslusi
1) Infeksi
2) Janin kembar
3) Riwayat hipertensi kronis.

Analisis univariat dengan menghitung nilai mean, median, standar deviasi dan distribusi frekuensi. Analisis dilakukan terhadap masing-masing variabel bebas dan variabel terikat seperti: umur ibu, gravida (riwayat obstetri), indeks massa tubuh (IMT), umur kehamilan, pendidikan, pekerjaan.

Hasil uji normalitas data di peroleh nilai $\mathrm{p}$ value $\leq 0,005$ yang berarti distribusi data tidak normal baik pada kelompok intervensi maupun kelompok kontrol. Berdasarkan hasil normalitas data tersebut dianalisis menggunakan uji Wilcoxon dan mann whitney test.

\section{Hasil dan Pembahasan}

A. Analisis Univariat Analisis univariat dilaksanakan terhadap data karakteristik responden meliputi umur ibu, indeks massa tubuh, umurkehamilan, pendidikan, pekerjaan.

Karakteristik berdasarkan umur ibu didapatkan rata-rata umur kelompok intervensi adalah 35 tahun 5 bulan dengan standar deviasi 6,77 , sedangkan rata-rata umur kelompok kontrol adalah 36 tahun 4 bulan dengan standar 5,23. Umur termuda pada kelompok intervensi 25 tahun dan umur tertua 45 tahun, sedangkan umur termuda pada kelompok kontrol 27 tahun dan tertua 41 tahun.

Umur adalah rentang kehidupan yang di ukur dengan tahun. Usia reproduksi adalah masa di antara pubertas dan menopause yang pembuahannya seringkali berhasil (positif). Usia sangat mempengaruhi kehamilan maupun persalinan. Usia yang baik untuk hamil atau melahirkan berkisar antara 2035 tahun. Pada usia tersebut alatalat reproduksi wanita telah berkembang dan berfungsi secara maksimal.

Hasil penelitian ini menunjukkan bahwa, rata-rata umur responden untuk kelompok intervensi adalah 35 tahun 5 bulan, sedangkan rata-rata umur kelompok kontrol adalah 36 tahun 4 bulan. Umur sangat berpengaruh terhadap kesehatan ibu hamil. Dalam penelitian ini rata-rata umur responden $\geq 35$ tahun, ibu hamil dengan usia lebih dari 35 tahun dapat meningkatkan risiko terjadinya preeklampsia.

Pada usia tersebut alat reproduksi wanita telah berkembang dan berfungsi secara maksimal.

Pada usia $>35$ tahun terjadi proses degeneratif yang mengakibatkan perubahan sruktural dan fungsional yang terjadi pada pembuluh darah perifer yang bertanggung jawab terhadap perubahan tekanan darah, sehingga lebih rentan mengalami preeclampsia.

Karakteristik berdasarkan IMT .

Dari hasil analisis di dapatkan rata-rata indeks massa tubuh (IMT) kelompok intervensi adalah 27,5 dengan standar deviasi 4,12, sedangkan rata-rata indeks massa tubuh (IMT) kelompok kontrol adalah 30,01 dengan standar 8,49. Nilai IMT terendah pada kelompok 
Jurnal Kebidanan Harapan Ibu Pekalongan

intervensi sebesar 21,60 dan tertinggi 32,80 . Sedangkan nilai IMT terendah pada kelompok kontrol sebesar 18,80 dan tertinggi 50,90.

Indek massa tubuh merupakan salah satu cara untuk mengetahui rentang berat badan sesorang. Metode ini digunakan untuk menentukan berat badan yang sehat berdasarkan berat dan tinggi badan. Mengukur IMT merupakan salah satu cara untuk mengidentifikasi kelebihan berat badan atau obesitas pada orang dewasa, yaitu dikategorikan obesitas jika IMT $\geq 25 \mathrm{~kg} / \mathrm{m} 2$ untuk wiilayah asia pasifik.

Dari hasil analisis didapatkan rata-rata indeks massa tubuh (IMT) kelompok intervensi adalah 27,5, sedangkan rata-rata indeks massa tubuh (IMT) kelompok kontrol adalah 30,01 .

Salah satu faktor yang berkaitan erat dengan terjadinya preeklampsia adalah obesitas. Ibu hamil dengan obesitas dua kali lebih berisiko mengalami preeklampsia dibandingkan ibu hamil dengan berat badan normal. Pada ibu hamil yang mengalami obesitas dapat terjadi preeklampsia melalui mekanisme hiperleptinemia, sindroma metabolik, reaksi inflamasi serta peningkatan stress oksidatif yang berujung pada kerusakan dan disfungsi endotel.

Karakteristik berdasarkan umur kehamilan

Dari hasil analisis di dapatkan rata-rata umur kehamilan responden kelompok intervensi adalah 28 minggu dengan standar deviasi 5,49, sedangkan rata-rata umur kehamilan kelompok kontrol adalah 29 minggu dengan standar 4,87. Umur kehamilan termuda pada kelompok intervensi adalah 21 minggu dan tertua 36 minggu. Sedangkan umur kehamilan termuda pada kelompok kontrol adalah 21 minggu dan tertua 36 minggu. Umur kehamilan memiliki kaitan yang erat dengan preeklampsia. Preeklampsia adalah suatu sindrom spesifik pada kehamilan yang terjadi setelah usia kehamilan 20 minggu, pada wanita yang sebelumnya normotensi. Proteinuria hanya timbul setelah kehamilan 20 minggu. Begitu juga dengan beberapa penanda lain preeklampsia juga mulai muncul setelah kehamilan memasuki 20 minggu.

Karakteristik Berdasarkan Pendidikan dan Pekerjaan.

Tabel 1. Karakteristik Berdasarkan Pendidikan dan Pekerjaan

\begin{tabular}{lcc}
\hline Variabel & $\begin{array}{c}\text { Kelompok } \\
\text { Kontrol }\end{array}$ & $\begin{array}{c}\text { Kelompok } \\
\text { Intervensi }\end{array}$ \\
\hline Pendidikan & & 7 \\
\hline Dasar & 9 & 2 \\
\hline Menengah & 1 & 1 \\
\hline PT & 0 & \\
\hline Pekerjaan & & 6 \\
\hline IRT & 8 & 1 \\
\hline Karyawan & 0 & 3 \\
\hline Dagang & 1 & 0 \\
\hline Buruh & 1 & \\
\hline & & \\
\hline
\end{tabular}


Jurnal Kebidanan Harapan Ibu Pekalongan

Dari hasil analisis distribusi karakteristik tingkat pendidikan responden pada kelompok intervensi mayoritas berpendidikan dasar $(70 \%)$ dan kelompok kontrol mayoritas berpendidikan dasar (90\%).

Dari hasil analisis distribusi karakteristik pekerjaan responden pada kelompok intervensi mayoritas pekerjaan sebagai ibu rumah tangga $(60 \%)$, dan kelompok kontrol sebagai pedagang dan buruh masingmasing $(10 \%)$.

Pendidikan merupakan proses pengubahan sikap dan tata laku seseorang atau kelompok orang dalam usaha mendewasakan manusia melalui upaya pengajaran dan pelatihan. Pendidikan berkaitan dengan daya akses dan daya tangkap seseorang terhadap informasi kesahatan. Pendidikan juga berkaitan dengan kesadaran seseorang akan pentingnya perilaku hidup sehat. Tingkat pendidikan seseorang mempengaruhi bagaimana seorang mengambil keputusan atas masalah kesehatan yang dialaminya. Semakin rendah pendidikan ibu maka akan semakin sedikit keinginan memanfaatkan pelayanan kesehatan (Rukmini, 2005). Ibu dengan pendidikan tinggi dan yang bekerja di sektor formal mempunyai akses yang lebih baik terhadap informasi tentang kesehatan, lebih aktif menentukan sikap dan lebih mandiri mengambil tindakan perawatan (Padila, 2014).

Pekerjaan adalah sesuatu yang dilakukan oleh manusia untuk tujuan tertentu yang di lakukan dengan cara yang baik dan benar. Dari hasil analisis distribusi karakteristik pekerjaan responden pada kelompok intervensi mayoritas pekerjaan sebagai ibu rumah tangga (60\%), dan kelompok kontrol sebagai pedagang dan buruh masingmasing (10\%). Ibu hamil yang tidak bekerja juga bersesiko mengalami preeklampsia dalam kehamilan karena sebagai IRT juga mengalami stres, karena mereka memiliki beberapa masalah rumahtangga yang berbeda-beda, seperti masalah ekonomi, masalah dengan keluarga, dan kecemasan akan kehamilan maupun persalinan.

B. Analisis Bivariat

Perbedaan Tekanan Darah Ibu Hamil Preeklampsia Sebelum Dan Sesudah Perlakuan Pada Kelompok Intervensi.

Tabel 2. Perbedaan Tekanan Darah Ibu Hamil Preeklampsia Sebelum Dan Sesudah Perlakuan Pada Kelompok Intervensi

\begin{tabular}{lll}
\hline Tekanan & Sebelum & Sesudah value \\
Darah & &
\end{tabular}

\begin{tabular}{llll}
\hline & Mean \pm SD & Mean \pm SD & \\
\hline Sistolik & $153 \pm 14,94$ & $135 \pm 8,49$ & 0,004 \\
\hline Distolik & $96 \pm 10,75$ & $88 \pm 7,88$ & 0,011 \\
\hline
\end{tabular}

$$
\text { Hasil }
$$
penelitian menunjukkan bahwa ada perbedaan perubahan tekanan darah baik sistolik maupun diastolik sebelum dan sesudah di berikan perlakuan terapi rendam kaki air hangat pada kelompok intervensi. Hasil analisis data di peroleh bahwa rata-rata tekanan darah sistolik sebelum perlakuan adalah $153 \mathrm{mmHg}$ dengan standar deviasi 14,94 dan tekanan darah diastolik 96 $\mathrm{mmHg}$ dengan standar deviasi 
Jurnal Kebidanan Harapan Ibu Pekalongan

10,75, sedangkan rata-rata tekanan darah sistolik setelah perlakuan $135 \mathrm{mmHg}$ dengan standar deviasi 8,49 dan tekanan darah diastolik $88 \mathrm{mmHg}$ dengan standar deviasi 7,88. Hasil uji statistik Wilcoxon menyimpulkan bahwa ada pengaruh pemberian terapi rendam kaki air hangat terhadap perubahan tekanan darah sistolik ibu hamil preeklampsia ( $\mathrm{p}=0,004 ; \alpha=$ 0,05) dan ada pengaruh terapi rendam kaki air hangat terhadap perubahan tekanan darah diastolik ibu hamil preeklampsia $(\mathrm{p}=0,011 ; \alpha=0,05)$.

Perbedaan Tekanan Darah Ibu Hamil Preeklampsia Sebelum Dan Sesudah Perlakuan Pada Kelompok Kontrol.

Tabel 3. Perbedaan Tekanan Darah Ibu Hamil Preeklampsia Sebelum Dan Sesudah Perlakuan Pada Kelompok Kontrol

\begin{tabular}{llll}
\hline $\begin{array}{c}\text { Tekanan } \\
\text { Darah }\end{array}$ & Sebelum & Sesudah & p value \\
\hline & Mean \pm SD & Mean \pm SD & \\
\hline Sistolik & $147 \pm 10,59$ & $149 \pm 12,86$ & 0,157 \\
\hline Distolik & $95 \pm 8,49$ & $95 \pm 8,49$ & 1,000 \\
\hline
\end{tabular}

Hasil penelitian menunjukkan bahwa tidak ada perbedaan perubahan tekanan darah baik sistolik maupun diastolik sebelum dan sesudah di berikan perlakuan intervensi edukasi pada kelompok kontrol. Hasil analisis data di peroleh bahwa rata-rata tekanan darah sistolik sebelum perlakuan adalah $147 \mathrm{mmHg}$ dengan standar deviasi 10,59 dan tekanan darah diastolik 95 $\mathrm{mmHg}$ dengan standar deviasi 8,49 , sedangkan rata-rata tekanan darah sistolik setelah perlakuan
$149 \mathrm{mmHg}$ dengan standar deviasi 12,86 dan tekanan darah diastolik $95 \mathrm{mmHg}$ dengan standar deviasi 8,49.

Hasil uji statistik Wilcoxon menyimpulkan bahwa tidak ada pengaruh pemberian intervensi edukasi terhadap perubahan tekanan darah sistolik ibu hamil preeklampsia $(\mathrm{p}=0,157 ; \alpha=$ $0,05)$ dan tidak ada pengaruh pemberian intervensi edukasi terhadap perubahan tekanan darah diastolik ibu hamil preeklampsia $(\mathrm{p}=1,000 ; \alpha=$ $0,05)$.

Hasil uji statistik MannWhitney nilai tekanan darah sistolik di peroleh $p$ value sebesar $0,000(\alpha=0,05)$. Hal ini menunjukkan bahwaada perbedaan perubahan tekanan darah sistolik antara kelompok intervensi dengan kelompok kontrol, sedangkan nilai tekanan darah diastolik diperoleh $p$ value sebesar 0,007 $(\alpha=0,05)$. Hal ini menunjukkan bahwa ada perbedaan perubahan tekanan darah diastolik antara kelompok intervensi dengan kelompok kontrol.

Rendam Kaki mengunakan air hangat yang dilakukan akan mempengaruhi kerja cerebral cortex dalam aspek kognitif maupun emosi, sehingga menghasilkan persepsi positif dan relaksasi, sehingga secara tidak langsung akan membantu dalam menjaga keseimbangan homeostasis tubuh. Melalui jalan HPA Axis, untuk menghasilkan Coticitropin Releasing Factor (CRF). Selanjutnya CRF merangsang kelenjar pituitary untuk menurunkan produksi ACTH sehingga produksi endorphin meningkat yang kemudian menurunkan produksi 
Jurnal Kebidanan Harapan Ibu Pekalongan

kortisol dan hormon-hormon stres lainnya sehingga menjadi rileks dan nyaman. Menurut Yeomans (2013), pada saat seseorang dihipnoterapi terjadi rangsangan terhadap sistem pengaktifasi retikulasi diotak, menyebabkan respon saraf otonom, yaitu penurunan nadi, tekanan darah, dan frekuensi nafas. Efek relaksasi dari hipnoterapi merangsang otak untuk memproduksi hormon enkafalin, endorphin, dan serotonin, semuanya merupakan hormon yang baik, sehingga terjadi respon saraf otonom yaitu penurunan tekanan darah, nadi, dan nafas.

\section{Kesimpulan}

Ada pengaruh pemberian terapi rendam kaki air hangat terhadap perubahan tekanan sistolik pada ibu hamil preeklampsia ( $p=0,004$; 0,05 ). Ada pengaruh pemberian terapi rendam kaki air hangat terhadap perubahan tekanan diastolik pada ibu hamil preeklampsia ( $p=$ $0,011 ; \leq 0,05)$.

\section{Daftar Pustaka}

[1] Ahmadi, Narbuko, Metode Penelitian, Jakarta: PT Bumi Aksara, 2009.

[2] Alilmul Aziz, Metode Penelitian Kebidanan Teknik Analisis Data, Salemba Medika, Jakarta, 2007.

[3] Bobak, Buku Ajar Keperawatan Maternitas. Ed.4. Jakarta: EGC, 2004

[4] Christinina Febri S, dkk, Efektivitas Rendam Kaki Dengan Air Hangat Terhadap PenurunanTekanan Darah Pada Ibu Hamil Penderita Preeklampsia Di Puskesmas Ngaliyan Semarang, Skripsi, Stikes Telogorejo, Tahun 2016.
[5] Dinas Kesehatan Provinsi Jawa Tengah, Profil Kesehatan Jawa Tengah, Tahun 2017.

[6] Dinas Kesehatan Kabupaten Pekalongan, Profil Kesehatan Kabupaten Pekalongan, Tahun 2017.

[7] Kartajin Atin, Modul Bahan Ajar Cetak Keperawatan Maternitas, Kementrian Kesehatan, Jakarta: Pusdik SDM Kesehatan, 2016

[8] Mochtar, Rustam. Sinopsis obstetri: Obstetri fisiologi, Obstetri Patologi,editor Delfi Lutan,Ed.2- Jakarta: EGC, 1998..

[9] Machfoeedz, Ircham, Statistik Nonparametrik Bidang Kesehatan, Keperawatan, Kebidanan, Kedokteran (BIOSTATISTIKA), cetakan ke2, Yogyakarta: Fitramaya, 2010

[10] Natiqotul F dkk, Determinan Maternal Kejadian Preeklampsia (Studi Kasus di Kabupaten Tegal, Jawa Tengah ), Jurnal Keperawatan Soedirman, Universitas Jendral Soedirman, vol.11, no 1, Maret 2016.

[11] Norma, Nita \& Mustika Dewi, Asuhan Kebidanan Patologi, Nuha Medika, Yogyakarta, 2018

[12] Padila, Asuhan Keperawatan Maternitas II, Yogyakarta: Nuha Medika, 2018.

[13] Riyanto Agus, Pengolahan Dan Analisis Data Kesehatan, Yogyakarta: Nuhan Medika, 2009.

[14] Prasetyo, Janah, Metode Penelitian Kuantitatif Teori Dan Aplikasi. Jakarta: PT Raja Grafinda Persada, 2007.

[15] Reny Yuli A, Buku Ajar Asuhan Keperawatan Maternitas Aplikasi NANDA, NIC dan NOC, CV. Jakarta: Trans Info Media, 2017. 
Jurnal Kebidanan Harapan Ibu Pekalongan

[16] Siti Khuzaiyah, dkk, Karakteristik Ibu Hamil

Preeklampsia, Jurnal Ilmiah

Kesehatan, vol.IX, no.2, ISSN 1978-3167, September 2016.

[17] Sukarni dkk, Patologi:

Kehamilan, Persalinan, Nifas dan

Neonatus Risiko Tinggi, Nuha

Medika, Yogyakarta, 2017. 